\title{
Heterobasidion spp, triggers non-specific defence responses in bark of Norway spruce
}

\author{
Malin Elfstrand ${ }^{1 *}$, Jenny Arnerup ${ }^{1}$, Karl Lundén ${ }^{1}$, Marie Danielsson², Marten Lind', Ake Olson', \\ Anna-Karin Borg-Karlsson², Jan Stenlid ${ }^{1}$ \\ From IUFRO Tree Biotechnology Conference 2011: From Genomes to Integration and Delivery \\ Arraial d'Ajuda, Bahia, Brazil. 26 June - 2 July 2011
}

Norway spruce [Picea abies (L.) Karst.] is one of the economically most important conifer species in Europe. The major pathogen on Norway spruce is Heterobasidion parviporum (Fr.) Niemelä \& Korhonen. The completed genome sequence of $H$. irregulare opens up new possibilities to understand the interactions between Heterobasidion spp. and spruce. However to date there are no completed genome sequencing projects of conifer genomes available for complementing studies. To achieve a better understanding of induced transcriptional defence responses in Norway spruce upon Heterobasidion spp. attack, we compared transcriptional responses in bark to $H$. parviporum infection to the response to wounding using cDNA-AFLP and transcriptome sequencing.

In an initial study bark samples were harvested at 3,7 and 14 days post inoculation (dpi) and untreated bark was used as negative control. About 2500 transcribed derived fragments (TDFs) generated by cDNA-AFLP were screened. 199 TDFs were investigated further based on band intensity in the inoculated bark in relation to either untreated bark or wounded bark. Out of these, 119 TDFs had a putative homology and a consistent band intensity pattern between replications. A majority of these TDFs showed homology to genes known to associate with defence e.g. 3-deoxy-d-arabinoheptulosonate 7-phosphate synthetase (DAHP), Pathogenesis-related protein 1 (PR1), Lipoxygenase (LOX), ACC-synthase (ACS), ACC-oxidase (ACO) and Jasmonate ZIM-domain 1 (JAZ1). Many of these are found in

\footnotetext{
* Correspondence: Malin.Elfstrand@slu.se

'Dept of Forest Mycology and Pathology, Swedish University of Agricultural

Sciences, Uppsala, Sweden

Full list of author information is available at the end of the article
}

Salicylic acid- or Jasmonic acid/ethylene-signalling pathways. The majority of the TDFs showed a similar expression pattern for all treatments but samples inoculated with $H$. parviporum generally showed an enhanced reaction (induction/repression) compared to wounding alone. Expression patterns were confirmed by qPCR in material treated with wounding and inoculation with H. parviporum or Phlebiopsis gigantea. Our data suggest that infection with $H$. parviporum in Norway spruce induces a broad defence, with many similarities to nonspecific defence responses in angiosperms. Additionally signs of reallocation of carbon from primary to secondary metabolism were evident.

With this information at hand we analysed four Norway spruce genotypes with either high or low susceptibility to Heterobasidion spp. [1] sampled 0, 5, 15 and 28 dpi with $H$. annosum. The bark phenol-composition was profiled in each sample. The 500,000 454-reads were assembled into 17,228 contigs that assembled in 14,364 putative transcript units (PTU) using the sequence assembler software Newbler ${ }^{\mathbf{T M}}$ (http:// www.454.com). The assembled reference file was annotated with the software Blast2Go and the PTUs were submitted to differential expression analysis. Data on associations between gene expression levels and phenol composition in bark upon $H$. annosum inoculation and level of susceptibility will be presented.

\footnotetext{
Author details

${ }^{1}$ Dept of Forest Mycology and Pathology, Swedish University of Agricultural Sciences, Uppsala, Sweden. ${ }^{2}$ Ecological Chemistry Group, Department of Chemistry, KTH, Stockholm, Sweden.
}

Published: 13 September 2011 


\section{Reference}

1. Karlsson B, Swedjemark G: Genotypic variation in natural infection frequency of Heterobasidion spp. in a Picea abies clone trial in southern Sweden. Scand J. Forest Research 2006, 21:108-114.

doi:10.1186/1753-6561-5-S7-030

Cite this article as: Elfstrand et al: Heterobasidion spp, triggers nonspecific defence responses in bark of Norway spruce. BMC Proceedings 2011 5(Suppl 7):030.

Submit your next manuscript to BioMed Central and take full advantage of:

- Convenient online submission

- Thorough peer review

- No space constraints or color figure charges

- Immediate publication on acceptance

- Inclusion in PubMed, CAS, Scopus and Google Scholar

- Research which is freely available for redistribution

Submit your manuscript at www.biomedcentral.com/submit
() Biomed Central 